\title{
On the Role and Implementation Methods of Music Education in Aesthetic Education in Higher Vocational Colleges
}

\author{
Ren Hua \\ JiangXi College of Traditional Chinese Medicine, FuZhou, 344000
}

Keywords: higher vocational colleges; music education; aesthetic education; function; implementation method

\begin{abstract}
At present, in the process of education in higher vocational colleges, the strengthening of music education is more conducive to the cultivation of aesthetic education for students, thus improving their comprehensive quality. In this paper, the role of music education in higher vocational colleges and implementation methods of aesthetic education are analyzed and discussed.
\end{abstract}

\section{Introduction}

With the continuous development of society, social competition is more and more fierce. Demand for technical talents is also increasing, and the cultivation of applied technical talents in higher vocational colleges occupies an important position, therefore, students pay more attention to the study of professional skills but neglect aesthetic education. Aesthetic education is aesthetic appreciation education or aesthetic sense education. By cultivating students' aesthetic standards, we mainly develop their ability to appreciate and create beauty. Aesthetic education plays an important role in the all-round development of human beings and is a necessary part of cultivating high-quality talents. It is the core of music education in higher vocational colleges. Therefore, in music education, we must pay attention to students' cultivation of feeling, appreciation, expression and creative ability of music, so as to play the role of aesthetic education in higher vocational colleges.

\section{Significance of Music Education in Aesthetic Education}

In higher vocational education, music education is to cultivate students' appreciation and understanding of music and other musical perception, so as to carry out aesthetic education. In this process, students' appreciation ability of beauty can be improved through the correct recognition and understanding of emotion and humanistic connotation in music works. In the process of selecting and appreciating music works, we should take the initiative to accept elegant and excellent works at home and abroad as well as reject vulgar and inferior works, effectively enhancing the appreciation ability and aesthetic quality, which is conducive to promote students to establish a positive world outlook and outlook on life. Thus, in music education, aesthetic education plays a very important role. In music education of higher vocational colleges, we should not just stay on the understanding of the surface layer of music, but also feel the connotation and expression of music works through deep understanding and study. In this way, students' aesthetic and appreciation ability can be improved, and the basic purpose of aesthetic education in music education is achieved. $^{[1]}$

\section{Present Situation of Music Education in Higher Vocational Colleges}

In modern society, the demand for talents focuses more on the practicality. Therefore, in the higher vocational education, in order to better meet the needs of society, improve employment rate, enhance the reputation of colleges in the society, and increase student source, higher vocational colleges stress more the cultivation of students' professional skills. Professional courses also account for a large proportion in teaching arrangements. Some colleges regard music teaching as a 
compulsory or optional course, but due to the low level of attention, their teaching conditions and weak teaching faculty, it is not possible to achieve good teaching results. ${ }^{[2]}$ On the other hand, although students take certain knowledge and understanding of music as a measure to regulate their mood, they usually only stay on pop music. Due to the development of pop music in today's society, students' understanding of music is becoming more and more limited, since they simply think that learning pop music is the learning and understanding of music. Under the influence of this situation, they only pay attention to pop music, but ignore the appreciation and understanding of those brilliant chapters created by Chinese and foreign musicians since ancient times, which makes the development of music teaching difficult and aesthetic education unable to play a role.

\section{Cultivation of Aesthetic Education in Music Teaching}

Music is a kind of art full of emotion. Plato once said: "Music has the most powerful power to invade the depths of soul and make our characters noble and beautiful." Through the creation and expression of emotion, music arouses resonance among listeners, and achieves the function of cultivating sentiment and directly attacking the soul. In music works, injection and expression of thoughts and emotion are the key and core of music composition. Therefore, in aesthetic education of music education, accurate analysis and feeling of emotion and thoughts contained in music are important methods of aesthetic education. It can be seen that in music education of colleges and universities, we must choose works with positive and healthy emotion to be integrated into teaching process according to students' spiritual needs, so as to improve their enthusiasm and guide them to establish a correct outlook on life, values and world outlook. ${ }^{[3]}$

In higher vocational colleges, it is necessary to strengthen student' aesthetic feeling ability, which is also a higher demand of higher vocational colleges and universities. Many colleges and universities have tried a series of methods for this purpose, for example, according to the different needs of students in different grades and different subjects, they select music works of high value, train music knowledge and skills, and then cultivate students' aesthetic sensitivity to music. Through practical activities of music, it is possible to improve their ability to appreciate music, to enhance their understanding of music, to improve their musical literacy, and to make them more adapt to the development of the times.

The cultivation of students' aesthetic discrimination ability includes the cultivation of distinguishing power of beauty and ugliness as well as the cultivation of nature, degree and type of musical beauty. Because of the variety of music in today's society, some students feel difficult to distinguish the beauty and ugliness of music, which leads some to immerse themselves in negative and world-weary songs, and some in music with unclean thoughts. Finally, cultural literacy of students is reduced to a great extent. Therefore, in music education of higher vocational colleges, it is very important to cultivate students' ability of correct aesthetic discrimination of music. Teachers should guide students to distinguish and recognize music, find more positive music and understand the beauty.

Music expresses and portrays vividly emotions through melody, tone, rhythm, harmony and other important elements. Among them, image and emotion are the most basic characteristics. Therefore, in the teaching of music, teachers should make great efforts to combine the image of music with the aesthetic characteristics of emotion and develop music appreciation activities to guide students. Under the correct guidance, students are able to expand their thinking and enrich their aesthetic experience.

In the education and teaching of higher vocational colleges, the ultimate goal is to cultivate students' sense of music, appreciation, creativity and aesthetic emotion. In music teaching, we are required to stress the following points when cultivating students' aesthetic creativity: The first one is to cultivate students aesthetic creative thinking ability. Thinking is the foundation of creation. Only by cultivating a good aesthetic creative thinking can aesthetic creativity be better cultivated. The second point is to cultivate students' ability of creative application of knowledge and artistic practice. Under the guidance of teachers, the ability of music activities can be displayed through creative music activities. ${ }^{[4]}$ The third point is to optimize the design of classroom teaching. On the 
basis of basic teaching, teachers must master flexible teaching methods and do not limit their teaching in the classroom. In extracurricular activities, students can also play a role in the main body of education through appropriate activities, so that music education in higher vocational colleges is really implemented on the aesthetic education of students.

\section{Implementation of Aesthetic Education in Music Education}

In higher vocational colleges, because students know very little about the professional knowledge of music, it is relatively easy to understand the teaching of aesthetic education through the form of music appreciation classes. The main characteristics of music is touching people with beauty and emotion. Teachers can directly enter into students' emotions by explaining and analyzing music works, purify students' hearts, effectively carry out aesthetic education, enable students to correctly understand, feel and appreciate music works. Music works of different periods have distinct styles, for example, classicism music is mainly to let students feel the rigorous and serious attitude and emotion of music works. Music works of Romantic period make students experience more of music freedom. Therefore, when teachers choose music, they should also choose more representative works according to students' actual situation. ${ }^{[5]}$

In the process of carrying out music aesthetic education in the form of music appreciation course, teachers should also combine the actual situation of students with the appreciation of music works. Since students in higher vocational colleges do not have a deep understanding of music major knowledge, if too much professional knowledge is involved in the appreciation of music, students will find it difficult to accept, thus reducing their interest in learning. Therefore, in the process of appreciating music works, a few references should be made to professional analysis, which can be analyzed in detail in terms of the background of the work and the expression of emotion, for example, in the course of appreciating Beethoven's "Symphony of Fate", students can learn about Beethoven's suffering. This piece was also written in writer's deaf condition, thus showing tenacity and perseverance. This kind of emotion can be used to appreciate music works. When appreciating the music of the Yellow River in China, we must convey patriotism to students. Teachers should also choose some works which reflect national spirits when choosing music works, so that students can baptize their hearts, strengthen their enthusiasm for learning and life, and establish a correct outlook on life and values.

It is very important for students to deepen their aesthetic ability by using the Second Classroom after the aesthetic education. In higher vocational colleges, aesthetic education can be cultivated by performing, appreciation meeting and so on through Art Group.

At present, in most higher vocational colleges, students' understanding of music is mostly limited to listening to songs and singing, but their musical accomplishment is not enough. Therefore, the key to aesthetic education of students' music education is to improve their musical quality. For this problem, we should not only strengthen education in classroom, but also give full play to the role of art troupe and related associations. It is suggested to carry out specific music theme activities penetrating various majors and all students. This kind of activity should not be a simple singing contest or performance, but what is more important is the improvement of students' musical quality and the enjoyment of aesthetic experience. For example, when holding relevant music activities, students must combine music emotion to fully interpret works and then perform the music. Through students' mutual understanding of music, aesthetic education can be promoted in activities.

In higher vocational colleges, through the guidance of teachers and learning of music appreciation courses, it is proposed to hold corresponding appreciation meeting of music works on campus. By choosing their favorite music works, students can introduce, explain and share their aesthetic feelings. In those activities, students will achieve a better understanding of the music works. At the same time, through communication between each other, they can also increase appreciative ability of music works, which makes students not only the participants but also the organizers in aesthetic education of music education. In music works, we can achieve the educational function of aesthetic education. 


\section{Conclusion}

With the development and progress of society, the higher the demand for talents is, the more important it is to cultivate comprehensive talents with high quality. Aesthetic education plays a very important role in education and teaching. As the main base of talent training, higher vocational colleges can better guarantee the effective output of high-quality talents through aesthetic education. By the cultivation of aesthetic education in music education, students can not only better understand and appreciate music works, but also are able to promote comprehensive accomplishment and set up correct outlook on life and values.

\section{Acknowledgements}

The work was supported by the project of teaching reform in colleges and universities in Jiangxi province in 2016 with the project number JXJG-16-44-2. And the project name Reflections on the "Red Classics" Music Appreciation Course in the Setting of Public Art Curriculum in Colleges and Universities.

\section{References}

[1] Jia Shiyan. On the Aesthetic Education Function and Implementation Approach of Music Education in Higher Vocational Colleges [J]. Journal of Sichuan Cadres Correspondence College, 2018 (01): 84 - 86.

[2] Jia Yangguo. Practical research on the Development of Music Education in Higher Vocational Colleges [J]. Music World, 2015 (10): 16-20.

[3] Yang Hao. Conception of Constructing Music Art Course in Higher Vocational Colleges under the Goal of "Creating Man with Good Morality" [J]. Journal of Guangzhou City Vocational College, 2016, 10 (02): 84-87.

[4] Xie Liwen. On the Function and Implementation of Music Education in Moral Education [J]. Journal of Wenzhou Institute of Vocational Technology, 2002 (01): 74-76.

[5] Zhou Shu. On the Importance of Music Appreciation in Quality Education in Higher Vocational Colleges [J]. Journal of Xiangtan Normal University (Social Sciences Edition), 2009,31 (05): 242-244. 